\title{
Serum paraoxonase and arylesterase activities in patients with lung
} cancer in a Turkish population

\author{
Emin T Elkiran*1, Nefsal Mar ${ }^{1}$, Bilge Aygen ${ }^{1}$, Ferit Gursu ${ }^{2}$, Aziz Karaoglu ${ }^{1}$ and \\ Suleyman Koca ${ }^{1}$
}

\author{
Address: ${ }^{1}$ Department of Internal Medicine, Firat (Euphrates) University School of Medicine, Elazig, Turkey and ${ }^{2}$ Department of Biochemistry and \\ Clinical Biochemistry, Firat (Euphrates) University School of Medicine, Elazig, Turkey \\ Email: Emin T Elkiran* - telkiran@yahoo.com; Nefsal Mar - nefsalmarh@yahoo.com; Bilge Aygen - btaygen@yahoo.com; \\ Ferit Gursu - fegursu@yahoo.com; Aziz Karaoglu - azizk6@yahoo.com; Suleyman Koca - kocassk@yahoo.com \\ * Corresponding author
}

Published: I5 March 2007

BMC Cancer 2007, 7:48 doi:10.1186/147/-2407-7-48

This article is available from: http://www.biomedcentral.com/147I-2407/7/48

(c) 2007 Elkiran et al; licensee BioMed Central Ltd.

This is an Open Access article distributed under the terms of the Creative Commons Attribution License (http://creativecommons.org/licenses/by/2.0), which permits unrestricted use, distribution, and reproduction in any medium, provided the original work is properly cited.
Received: 8 December 2006

Accepted: 15 March 2007

\begin{abstract}
Background: Lung cancer (LC) is the leading cause of cancer-related deaths. Oxidative DNA damage may contribute to the cancer risk. The antioxidant paraoxonase (PONI) is an endogenous free radical scavenger in the human body. The aim of this study was to determine serum PONI and arylesterase (ARE) activities in patients with newly diagnosed LC.

Methods: This case control study involved a total of 39 patients with newly diagnosed LC (untreated) and same number of age- and sex-matched healthy individuals. Serum PONI and ARE activities in addition to lipid parameters were measured in both groups.

Results: Serum PONI and ARE activities were found to be lower in patients with LC compared to the controls $(p=0.00 \mathrm{I}$ and $p=0.018$, respectively). The ratio of $\mathrm{PONI} /$ high density lipoprotein (HDL) was significantly lower in the LC group compared to the control one $(p=0.009)$. There were positive correlations between the serum levels of HDL and PONI in both the control $(r=$ $0.4 I 5, p=0.009)$ and the LC groups $(r=0.496, p=0.00 \mathrm{I})$, respectively. PONI enzyme activity was calculated as three different phenotypes in both groups. In regard to lipid parameters, total cholesterol levels were significantly lower $(p=0.014)$ in the LC group whereas the other lipid parameters such as HDL, LDL, and triglyceride levels were not significantly different among groups.

Conclusion: Serum PONI activity is significantly low in the LC group compared with the healthy controls. Metastasis status and cigarette smoking do not affect serum PONI activity in the LC patients.
\end{abstract}

\section{Background}

Lung cancer (LC) is among the most common malignancies in the Western World and is the leading cause of cancer deaths in both men and women. It is one of the few tumors with a known carcinogen, namely tobacco, contributing to its etiology. Since cigarette smoking was noted in $80 \%$ to $90 \%$ of patients with LC, the leading cause of LC is accepted to be smoking $[1,2]$.

An elevated oxidative status has been found in many types of cancer cells, and the introduction of chemical and enzymatic antioxidants can inhibit tumour cell proliferation 
[3]. High doses and/or inadequate removal of reactive oxygen species (ROS) result in oxidative stress, which may cause severe metabolic malfunctions and damage to biological molecules including DNA [4]. It is well known that oxidative stress induced by environmental carcinogen exposure may affect cellular functions in various pathological conditions, including cancer $[5,6]$.

Human serum paraoxonase (PON1) and arylesterase (ARE) are esterase enzymes that have lipophilic antioxidant characteristics. Serum PON1 binds to high density lipoprotein (HDL) and contributes to the elimination of organophosphorus compounds, such as paraoxon, and carcinogenic lipid soluble radicals from lipid peroxidation. PON1 is one of the endogenous free-radical scavenging systems in the human body [7-9]. Serum PON1 together with ARE have been demonstrated to function as a single enzyme [10]. PON1 activity varies widely among individuals, partly related to polymorphisms. The PON1 gene has two common coding region polymorphisms [11]. A genetic polymorphism of PON1 activity determines high versus low paraoxon hydrolysis in human populations [12]. PON1 also has ARE activity, which does not exhibit activity polymorphism and can therefore serves as an estimate of enzyme protein [13]. Human serum PON1 shows neither age-related change in activity nor gender differences [14]. However, diet, cigarette smoking, acute phase proteins, and pregnancy affect serum PON1 levels and activities [15-17]. Reduced PON1 activities have been reported in several groups of patients with diabetes mellitus, hypercholesterolemia and cardiovascular disease who are under increased oxidative stress $[18,19]$. There are relatively few studies on in PON1 activity in cancer. Serum levels of PON1 were lower in patients with pancreatic or gastric cancer than in healthy controls in two case-control studies. Despite these initial findings, the interaction of serum PON1 levels with cancer is not completely known $[15,20,21]$. It has been emphasized that PON1 polymorphisms might contribute to the increased risk of cancer in associated with pollutants and other environmental chemicals [22].

The aim of this study was to investigate the activity of serum PON1 in patients with LC, compared to that of healthy controls, and to investigate possible alterations in relation to the stage and type of LC.

\section{Methods}

\section{The study population}

This case-control study was conducted at the Department of Internal Medicine of the Firat (Euphrates) University Hospital setting in Elazig, Turkey, between December 2004 and June 2005. A total of 44 patients were admitted during the period. However two of them were excluded from the study due to history of taking antilipidemic drug, three of them were also not eligible for the study due to history of taking chemotherapy. The remaining 39 patients with previously untreated, histopathologically verified newly diagnosed as of LC and 39 age- and sexmatched healthy volunteers were enrolled into this study. Informed consents were obtained from patients prior to the study. The study protocol and the procedures were approved by Firat University Local Ethical Committee, and all subjects were recruited upon obtaining informed consent. Subjects' history and physical examinations were documented. The diagnosis of LC was based on histopathologic findings. Nine out of 39 patients were small cell LC, 16 were squamous cell LC, 14 were adenocarcinoma type. Cases either study group or control, who had pathologies that could cause secondary lipid disorders, cardiovascular diseases, diabetes mellitus, renal failure, chronic infection and inflammation, alcohol abuse, and those who used antilipidemic and antioxidant drugs were excluded from the study. Additionally, LC patients with previously performed chemotherapy, radiotherapy and surgery were also excluded from the study.

\section{Serum samples}

Blood samples were collected in tube (BD diagnostics-preanalytic systems, UK) at 0800-0900 A.M. after 8-12 hours of fasting. Professional staff performed venipuncture, using vacutainers to obtain $10 \mathrm{~mL}$ of whole blood. Since calcium EDTA inhibits PON1 activity, calcium EDTA containing tubes were not used for collecting serum samples. The samples were centrifuged at $3500 \mathrm{rpm}$ for 5 min. and serum samples were stored at $-20^{\circ} \mathrm{C}$ until assayed.

Serum levels of total cholesterol, triglyceride, HDL-cholesterol and low density lipoprotein (LDL)-cholesterol were determined by means of an Olympus AU 600 autoanalyzer (Olympus Optical Co., Japan) using commercially available assay kits. Serum total cholesterol, triglyceride, HDL-cholesterol and LDL-cholesterol levels were measured at the same day that the blood was collected.

\section{Assay of serum paraoxonase and arylesterase activities}

Paraoxonase activity was determined spectrophotometrically using paraoxon (O, O-diethyl-o-p-nitro-phenylphosphate; Sigma Chemical Co) as the substrate and measured by increases in the absorbance at $412 \mathrm{~nm}$ due to the formation of 4-nitrophenol as already described [23]. Briefly, the activity was measured at $25^{\circ} \mathrm{C}$ by adding $50 \mu \mathrm{l}$ of serum to $1 \mathrm{ml}$ Tris- $\mathrm{HCl}$ buffer $(100 \mathrm{nM}$ at $\mathrm{pH} 8.0)$ containing $2 \mathrm{mM} \mathrm{CaCl} 2$ and $5.5 \mathrm{mM}$ of paraoxon. The rate of generation of 4-nitrophenol was determined at $412 \mathrm{~nm}$ with a spectrophotometer (Techcomp 8500 II UV/VIS, China). PON 1 activity is expressed in $\mathrm{U} / \mathrm{l}$ serum. One unit of PON1 activity was defined as $1 \mathrm{nmol}$ of 4-nitrophenol formed per minute under the above assay conditions. 
Arylesterase activity was also measured spectrophotometrically using phenylacetate (Sigma Co, London, UK) as the substrate. The phenol formed after the addition of a 40-fold diluted serum sample was measured spectrophotometrically at $217 \mathrm{~nm}$ following an established procedure [24]. The activity of ARE was expressed in kU/l serum. One unit was defined as the enzyme quantity that disintegrates $1 \mathrm{nmol}$ phenylacetate per minute.

\section{The phenotypic distribution of paraoxonase}

The phenotypic distribution of PON1 activity was determined by the dual substrate method. Three phenotypes were determined in the study groups by taking the ratio of PON1 activity to arylesterase activity. The ratio of hydrolysis of paraoxon in the presence of $1 \mathrm{M} \mathrm{NaCl}$ (salt-stimulated PON1) to the hydrolysis of phenylacetate was used to classify individuals to one of the three possible phenotypes; AA (homozygote low activity), AB (heterozygote activity) and BB (homozygote high activity) [25]. Phenotype of PON1 activity according to the PON1/ARE rate was also performed individually for each group and three different phenotypes were determined for each group. The PON1/ARE rates of LC patients were considered as: $0.56-$ 1.55 AA, 1.56-3.10 AB and 3.11-4.66 BB phenotypes, respectively. The PON1/ARE rates for the control group were considered as: $0.94-1.14$ AA, $1.15-2.28$ as AB, 2.293.50 as $\mathrm{BB}$ phenotypes, respectively.

\section{Statistical analysis}

Statistical analyses were performed using the SPSS software package, version 10.0 for Windows. Clinical laboratory data were expressed as mean \pm standard deviation. Mean values were compared between patients with LC and healthy individuals by Student's $t$ test. Mann Whitney- $U$ test was used to assess the mean differences between smoker LC patients and smoker control, and between metastatic and nonmetastatic LC patients. The Pearson's correlation analysis was used to assess the relationship between PON1 activity and HDL cholesterol levels. The analysis of variance (ANOVA) test was used to compare biochemical parameters among small cell carcinoma, squamous cell carcinoma and adenocarcinoma.

Stepwise multivariate linear regression analyses (with $95 \%$ confidence intervals) were performed by considering the PON1 activity as the dependent variable. The possible associations between serum PON1 and independent variables (total cholesterol, HDL cholesterol, triglyceride levels, stage of disease and metastasis status) were followed. A value of $p<0.05$ was considered as statistically significant.

\section{Results}

The demographic features and biochemical parameters of LC patients and controls are presented in the Table 1. Out of the 39 patients with LC, 38 (97\%) of the patients were males and $1(3 \%)$ was female. The mean age was $64.4 \pm$ 8.9 years (range, 50-85 years). Thirty had non-small cell LC (16 squamous cell LC, 14 adenocarcinoma type), nine had small cell LC. Patients were staged according to the American Joint Committee on Cancer (AJCC) staging system. Nine patients had stage II disease, 10 had stage III and the remaining 20 had stage IV disease. The control group was consisted of 39 healthy individuals, 38 males and 1 female with mean age of $64.05 \pm 8.6$ years (range, 50-85 years). The mean age and sex distribution were similar in both groups. In addition, there was no difference in race among groups. The mean serum PON1 activities were $395.8 \pm 116.6 \mathrm{U} / \mathrm{mL}$ and $252.7 \pm 104.4 \mathrm{U} / \mathrm{mL}$ in the control group and in the patients with $\mathrm{LC}$, respectively. When compared to healthy controls, serum ARE activity were lower in patients with LC which was statistically significant (Table 1). Serum HDL cholesterol, LDL cholesterol and triglyceride levels were not significantly different among groups. Although not statistically significant, the HDL cholesterol levels, serum HDL level and PON1 activity were lower in LC patients. The PON1 activity was standardized with HDL concentrations (PON1/ HDL ratio). It was found that the standardized PON1 enzyme activity was significantly lower in the LC patients $(8.1 \pm 2.9)$ as compared with controls $(9.8 \pm 2.9 ; \mathrm{p}=$ $0.009)$. The serum total cholesterol level in patients with LC was significantly lower compared with healthy subjects $(\mathrm{p}=0.014)$ (Table 1$)$.

There was no statistical difference between the biochemical parameters among small cell carcinoma, squamous cell carcinoma and adenocarcinoma in any stage (Table 2).

It was found in the smoker LC patients that serum PON1 and ARE activities was significantly lower compared with smoker controls. Serum PON1 activity in the smoker LC patients was markedly lower $(\mathrm{p}<0.001)$ than that of the smoker control subjects. Similarly, serum ARE activity in the smoker LC patients was lower. Serum ARE activities were $175.3 \pm 48.7 \mathrm{U} / \mathrm{L}$ and $143.6 \pm 57.3 \mathrm{U} / \mathrm{L}$; in the smoker control subjects and in the smoker LC patients, respectively $(\mathrm{p}=0.025)$. In the smoker control subjects, serum HDL cholesterol levels were significantly higher ( $\mathrm{p}$ $<0.001$ ) than that of the smoker LC patients (Table 3 ).

As shown in the Table 4, no statistically significant differences were observed in serum PON1 and ARE activities between metastatic and nonmetastatic LC patients. Serum PON1 activity was $259.5 \pm 94.9 \mathrm{U} / \mathrm{mL}$ in the patients with metastatic LC whereas it was $245.6 \pm 115.7 \mathrm{U} / \mathrm{mL}$ in the patients with nonmetastatic LC $(\mathrm{p}=0.70)$. The mean serum ARE activities were 153.9 $\pm 62.9 \mathrm{U} / \mathrm{L}$ and $153.9 \pm$ 
Table I: Demographic features, paraoxonase activity and biochemical parameters in controls and lung cancer patient groups

\begin{tabular}{llll}
\hline & Control group $(\mathrm{n}=39)$ & Patient group $(\mathrm{n}=39)$ & $P$ value \\
\hline Age (year) & $64.0 \pm 8.6$ & $64.4 \pm 8.9$ & 0.861 \\
Cigarette smoking $(\%)$ & 64.1 & 89.7 & 0.014 \\
Total cholesterol $(\mathrm{mg} / \mathrm{dl})$ & $193.2 \pm 48.5$ & $165.1 \pm 50$ & 0.014 \\
LDL cholesterol $(\mathrm{mg} / \mathrm{dl})$ & $128.8 \pm 35.3$ & $116 \pm 42.4$ & 0.152 \\
HDL cholesterol $(\mathrm{mg} / \mathrm{dl})$ & $41.7 \pm 10.9$ & $34.9 \pm 20.8$ & 0.074 \\
VLDL cholesterol $(\mathrm{mg} / \mathrm{dl})$ & $32 \pm 16.3$ & $29.3 \pm 11.5$ & 0.393 \\
Triglyceride $(\mathrm{mg} / \mathrm{dl})$ & $160.8 \pm 81.7$ & $141.3 \pm 53.9$ & 0.219 \\
PONI (U/mL) & $395.8 \pm 116.6$ & $252.7 \pm 104.4$ & 0.001 \\
ARE (U/L) & $167.7 \pm 45$ & $137.4 \pm 57.6$ & 0.018 \\
PONI/ARE & $2.4 \pm 0.6$ & $2.0 \pm 0.9$ & 0.008 \\
PON/HDL & $9.8 \pm 2.9$ & $8.1 \pm 2.9$ & 0.009 \\
\hline
\end{tabular}

Values are mean \pm S.D. PONI: paraoxonase, ARE: arylesterase

62.9 U/L in the metastatic LC patients and in the nonmetastatic LC patients $(\mathrm{p}=0.09)$.

We determined the phenotype distribution of our study groups by taking the ratio of PON1 activity to arylesterase activity. The distribution of paraoxonase phenotypes in LC patients and controls was as follows: AA (homozygote low activity), 36\% and 3\%, $\mathrm{AB}$ (heterozygote activity) $51 \%$ and $35 \%$, BB (homozygote high activity) $13 \%$ and $62 \%$, respectively. Serum PON1 levels in the individuals with $\mathrm{AA}, \mathrm{AB}$, and $\mathrm{BB}$ phenotypes in the $\mathrm{LC}$ group were lower than the same phenotype individuals in the control group.

There was established positive correlation between serum PON1 activity and serum level of HDL cholesterol $(r=$ $0.496, \mathrm{p}=0.001$ ) in patients with LC. Similarly, serum PON1 activity also correlated positively with serum HDL cholesterol level $(\mathrm{r}=0.415, \mathrm{p}=0.009)$ in the control group (Figures 1 and 2).

Multiple linear regression analysis of the variables was also performed by considering the PON1 as the dependent variable. It was determined that total cholesterol, HDL cholesterol, triglyceride levels, stage of disease and pres- ence or absence of metastasis was not the determining factor for the PON1 activity (Table 5).

\section{Discussion}

Reactive oxygen species molecules are highly reactive and can attack almost every cell component, causing further damage to the surrounding tissues. An elevated oxidative stress and free oxygen radicals have been associated with the increased risks of various cancers. End products of lipid peroxidation and scavenging system elements have been thought to play a role in oncogenesis [26-28]. Kaynar et al. studied the activities of antioxidant enzymes and demonstrated that erythrocyte malondialdehyde, nitric oxide, total glutathione levels and erythrocyte superoxide dismutase, catalase and xanthine oxidase activities were significantly higher in patients with LC than in controls. This study indicates significant changes in antioxidant defense system in LC patients, which may lead to enhanced action of oxygen radicals, resulting in lipid peroxidation [29]. One of the lipid peroxidation end products, malondialdehyde level in patients with LC has been found significantly higher than those in controls [30]. Carcinogenic lipid soluble radicals are formed as a result of lipid peroxidation and PON1 binds to these radicals. PON1 has been shown to metabolize lipid-soluble radi-

Table 2: Serum paraoxonase activity and biochemical parameters in small cell lung cancer adenocarcinoma and epidermoid carcinoma patient groups

\begin{tabular}{|c|c|c|c|c|}
\hline & $\operatorname{SCLC}(n=9)$ & $A C(n=14)$ & $E C(n=16)$ & $P$ value \\
\hline Total cholesterol (mg/dl) & $158.9 \pm 30.7$ & $170.9 \pm 45.6$ & $163.5 \pm 63.1$ & 0.849 \\
\hline LDL cholesterol (mg/dl) & $115.4 \pm 26.3$ & $\mid 18.2 \pm 41.1$ & $114.4 \pm 52.1$ & 0.971 \\
\hline HDL cholesterol (mg/dl) & $30.3 \pm 4.3$ & $34.2 \pm 9.9$ & $38 \pm 31.3$ & 0.680 \\
\hline VLDL cholesterol (mg/dl) & $33.9 \pm 15$ & $27.8 \pm 8.7$ & $28.1 \pm 11.6$ & 0.504 \\
\hline Triglyceride (mg/dl) & $158.8 \pm 68.8$ & $131.4 \pm 37.1$ & $|40| \pm 58.2$. & 0.395 \\
\hline PONI (U/mL) & $233.9 \pm 70.5$ & $273.1 \pm 118.1$ & $245.4 \pm 110.5$ & 0.649 \\
\hline ARE (U/L) & $163 \pm 69.5$ & $1 \mid 5.7 \pm 44.2$ & $142 \pm 57.2$ & 0.144 \\
\hline PONI/ARE & $1.7 \pm 0.9$ & $2.5 \pm 0.9$ & $1.8 \pm 0.7$ & 0.062 \\
\hline
\end{tabular}

Values are mean \pm S.D. SCLC:Small Cell carcinoma, AC: Adenocarcinoma, EC:Epidermoid carcinoma, PONI: paraoxonase, ARE: arylesterase 
Table 3: Paraoxonase and arylesteraz activies in smoker controls and smoker lung cancer patients

\begin{tabular}{llll}
\hline & Smoker controls $(\mathrm{n}=25)$ & Smoker LC patients $(\mathrm{n}=35)$ & $P$ value \\
\hline PONI (U/mL) & $412.9 \pm 121.9$ & $263.8 \pm 104.5$ & 0.001 \\
ARE $(\mathrm{U} / \mathrm{L})$ & $175.3 \pm 48.7$ & $143.6 \pm 57.3$ & 0.025 \\
HDL cholesterol $(\mathrm{mg} / \mathrm{dl})$ & $42.6 \pm 11.1$ & $32.6 \pm 8.6$ & 0.001 \\
PONI/HDL cholesterol & $10 \pm 3.2$ & $8.3 \pm 3.3$ & 0.047
\end{tabular}

Values are mean \pm S.D. LC: Lung cancer, PONI: paraoxonase, ARE: arylesterase

cals [15,31]. Serum PON1 activity was suggested to be inversely associated with oxidative stress in serum and macrophages and that PON1 deficiency results in increased oxidative stress [32]. In our study, serum PON1 activity was found to be significantly lower in patients with LC compared to healthy individuals. Some studies have established a positive correlation between PON1 mutations and the risk of cancer. However, the data are conflicting and other studies revealed no evidence for an association with malignancy. A case-control study which contains 177 patients by Lee et al. [33] showed that the risk of developing LC were significantly increased in individuals carrying the PON1 gene Q/Q genotype. It was also stated that, this correlation could not be established with the $\mathrm{R} / \mathrm{R}$ or $\mathrm{Q} / \mathrm{R}$ genotypes of the PON1 gene in this study. To the best of our knowledge, our study is the first to state the association between PON1 and LC in the English Literature. Similar to the aforementioned study, we observed that in LC patients, PON1 activity was reduced and not influenced by the cigarette smoking and metastasis status of subjects. In our study, we have not performed any genotypical analysis due to technical limitations. Kerridge et al. [34] found that PON1 BB gene (Arg 192 isoform) polymorphism was associated with risk of non-Hodgkin's lymphoma. A cohort study found no association between PON1 polymorphism and prostate cancer [35], whereas another case-control study demonstrated that men with PON192/QQ had a significantly increased risk for prostate cancer compared with PON192/RR genotype [36]. In a prospective study of Stevens et al. it was reported that L55 M PON1 genotype may have increased risk factor for breast cancer in postmenopausal women, whereas the Q192R single nucleotide polymorphism was not associ- ated with breast cancer incidence [37]. The study of Kafadar et al. showed that serum PON1 activity is significantly lower in patients with high grade glioma and meningioma compared to control subjects [38]. Other investigators have not reported any significant differences in PON1 genotype distributions in patients with colorectal cancer comparison to healthy individuals [39].

In our study, we found decreased activities of PON1 and ARE enzymes in patients with LC comparison to the group of healthy individuals. To assess whether the observed reduction of PON1 activity was due to the reduced HDL level, we standardized the enzyme activity for HDL concentration (PON1/HDL) and found that the standardized enzyme activities were lower in patient group compared to the controls $(\mathrm{p}=0.009)$. Positive correlation was determined between serum PON1 activity and HDL cholesterol. These data indicate that PON1 activity changes are not entirely dependent on HDL concentration in this study group.

Lipid peroxidation, as a well-known index of ROS activity, is an oxidative stress associated with membrane lipid destruction. Previous studies have reported increased lipid peroxidation in cancer tissues, in serum and in erythrocytes of patients with $\mathrm{LC}[30,40,41]$. The serum PON1 activity is highly variable and its regulation is complex. Moreover the mechanism of the reduction of serum PON1 activity in LC patients is not clearly understood. This reduction could be related to increased lipid peroxidation, since oxidized lipids are reported to inhibit PON1 activity [42]. In addition, the activity of PON1 has been reported to be significantly reduced in some conditions

Table 4: Paraoxonase activity and biochemical parameters in metastatic and non-metastatic lung cancer patients

\begin{tabular}{llll}
\hline & Nonmetastatic LC patients $(\mathrm{n}=19)$ & Metastatic LC patients $(\mathrm{n}=20)$ & $P$ value \\
\hline Total cholesterol $(\mathrm{mg} / \mathrm{dl})$ & $169.7 \pm 57.6$ & $160.7 \pm 42.7$ & 0.66 \\
LDL cholesterol $(\mathrm{mg} / \mathrm{dl})$ & $115.3 \pm 45.8$ & $116.6 \pm 40.1$ & 0.94 \\
HDL cholesterol $(\mathrm{mg} / \mathrm{dl})$ & $38.8 \pm 28.5$ & $31.1 \pm 8.1$ & 0.62 \\
Triglyceride $(\mathrm{mg} / \mathrm{dl})$ & $149.9 \pm 55.7$ & $133.2 \pm 52.4$ & 0.41 \\
PONI $(\mathrm{U} / \mathrm{mL})$ & $245.6 \pm 115.7$ & $259.5 \pm 94.9$ & 0.70 \\
ARE $(\mathrm{U} / \mathrm{L})$ & $120 \pm 47$ & $153.9 \pm 62.9$ & 0.09 \\
\hline
\end{tabular}

Values are mean \pm S.D. LC: Lung cancer, PONI: paraoxonase, ARE: arylesterase 


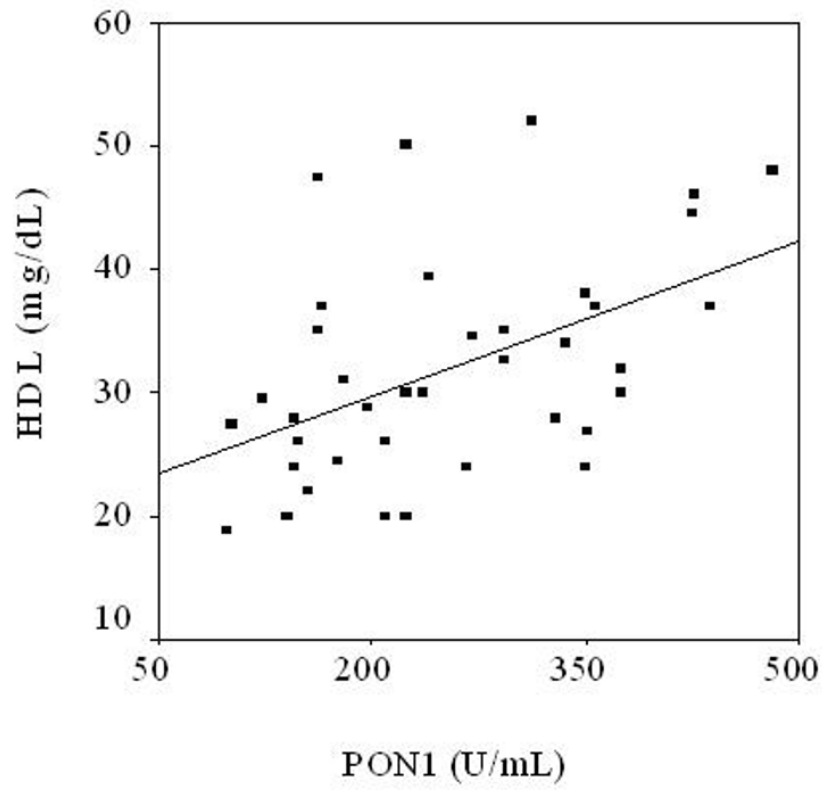

Figure I

Positive correlation between serum HDL concentration and PONI activity in the LC group $(r=0.496, p=0.00 \mathrm{I})$.

accompanying oxidative stress and inflammatory conditions, including rheumatoid arthritis, ulcerative colitis and Behcet's disease $[43,44]$. Similarly, reduced serum

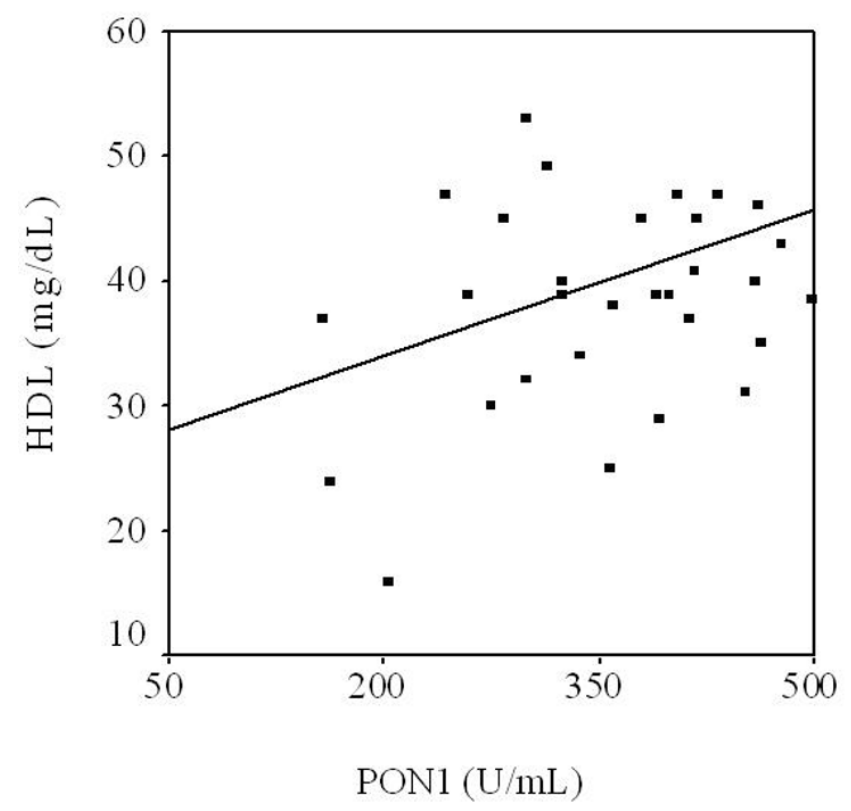

Figure 2

Positive correlation between serum HDL concentration and PONI activity in the control group $(r=0.415, p=0.009)$.
PON1 activity in patients with LC could be a result of increased activity of ROS in LC. Cigarette smoking has also been shown to decrease serum PON1 levels and activity [45]. In our study, when smoking status of each group were considered, we found that in the smoker LC patients, serum PON1 and ARE activities was significantly lower compared with smoker healthy controls ( $\mathrm{p}<0.001)$. Standardized enzyme activities of PON1/HDL were also lower in smoker patient group compared to smoker controls $(\mathrm{p}=0.047)$. These results suggest the reduction of PON1 activity in patients with LC was independent from cigarette smoking.

\section{Conclusion}

This study showed that serum PON1 and ARE activities were significantly lower in LC patients compared to healthy subjects. These observations suggested the hypothesis that defects in the antioxidant system capacity and altered PON1 activity may be involved in the pathogenesis of LC. But, these preliminary results are needed to be verified by large numbered prospective studies to reveal the possible association between PON1 and LC.

\section{Competing interests}

The author(s) declare that they have no competing interests.

\section{Authors' contributions}

ETE: Have made substantial contributions to conception, design, interpretation of data, and drafting the manuscript.

NM: Have made substantial contributions to acquisition of data and design of the study.

BA: Have been involved in drafting the manuscript and contributed to the intellectual content of the manuscript and design of the study.

FG: Have been involved in acquisition, analysis and interpretation of the data.

AK: Have contributed to the intellectual content of the manuscript.

SK: Have been involved in acquisition, statistical analysis of the data.

All authors read and approved the final manuscript. 
Table 5: Multiple linear regression model with paraoxonase as the dependent variable

\begin{tabular}{|c|c|c|c|c|}
\hline & Standardized Coefficients Beta & $\mathrm{t}$ & $P$ & $95 \% \mathrm{Cl}$ \\
\hline \multicolumn{5}{|l|}{$95 \% \mathrm{Cl}$} \\
\hline Age & -0.050 & -0.650 & 0.521 & -2.4 to 1.3 \\
\hline Sex & 0.028 & 0.356 & 0.725 & -85.9 to 121.9 \\
\hline Total cholesterol & $0.4 \mid 4$ & $\mathrm{I} .754$ & 0.092 & -0.2 to 1.9 \\
\hline LDL cholesterol & -0.260 & -1.115 & 0.276 & -1.8 to 0.5 \\
\hline HDL cholesterol & -0.118 & -1.378 & 0.181 & -1.5 to 0.3 \\
\hline VLDL cholesterol & -0.294 & -1.415 & 0.169 & -1.4 to 0.3 \\
\hline Triglyceride & 0.089 & 0.447 & 0.659 & -2.9 to 4.5 \\
\hline Stage & 0.248 & I.I46 & 0.263 & -26.7 to 93.7 \\
\hline Metastasis status & -0.266 & -1.258 & 0.220 & -144 . to 34.9 \\
\hline
\end{tabular}

$\mathrm{Cl}$ : Confidence Interval

\section{Acknowledgements}

We are grateful to Vedat Bulut for critical reading, copyediting and reorganizing of the manuscript. This work was supported by Firat (Euphrates) University through its institutional facilities.

\section{References}

I. Hoffman PC, Mauer AM, Vokes EE: Lung cancer. Lancet 2000, 355:479-485.

2. Minna JD, Roth JA, Gazdar AF: Focus on lung cancer. Cancer Cell 2002, I:49-52.

3. Behrend L, Henderson G, Zwacka RM: Reactive oxygen species in oncogenic transformation. Biochem Soc Trans 2003, 3 I: $144|-| 444$.

4. Cejas P, Casado E, Belda-Iniesta C, De Castro J, Espinosa E, Redondo A, Sereno M, Garcia-Cabezas MA, Vara JA, Dominguez-Caceres A, et al.: Implications of oxidative stress and cell membrane lipid peroxidation in human cancer (Spain). Cancer Causes Control 2004, I 5:707-719.

5. Goldstein BD, Witz G: Free radicals and carcinogenesis. Free Radic Res Commun 1990, I I:3-10.

6. Ames BN: Dietary carcinogens and anticarcinogens. Oxygen radicals and degenerative diseases. Science 1983, 22 I: $\mid 256-1264$.

7. Aviram M, Rosenblat M, Bisgaier CL, Newton RS, Primo-Parmo SL, La Du BN: Paraoxonase inhibits high-density lipoprotein oxidation and preserves its functions. $A$ possible peroxidative role for paraoxonase. J Clin Invest 1998, I 0 I: I58 I- I590.

8. Mackness MI, Arrol S, Durrington PN: Paraoxonase prevents accumulation of lipoperoxides in low-density lipoprotein FEBS Lett 199I, 286: I52-I54.

9. Li HL, Liu DP, Liang CC: Paraoxonase gene polymorphisms, oxidative stress, and diseases. I Mol Med 2003, 81:766-779.

10. Gan KN, Smolen A, Eckerson HW, La Du BN: Purification of human serum paraoxonase/arylesterase. Evidence for one esterase catalyzing both activities. Drug Metab Dispos 1991, 19:100-106.

II. Aynacioglu AS, Cascorbi I, Mrozikiewicz PM, Nacak M, Tapanyigit EE, Roots I: Paraoxonase I mutations in a Turkish population. Toxicol Appl Pharmacol 1999, I57:174-177.

12. Humbert R, Adler DA, Disteche CM, Hassett C, Omiecinski CJ, Furlong $C E$ : The molecular basis of the human serum paraoxonase activity polymorphism. Nat Genet 1993, 3:73-76.

13. Nevin DN, Zambon A, Furlong CE, Richter RJ, Humbert R, Hokanson JE, Brunzell JD: Paraoxonase genotypes, lipoprotein lipase activity, and HDL. Arterioscler Thromb Vasc Biol 1996 16:1243-1249.

14. Geldmacher-von Mallinckrodt M, Diepgen TL, Duhme C, Hommel G: A study of the polymorphism and ethnic distribution differences of human serum paraoxonase. Am J Phys Anthropol 1983, 62:235-24I.

15. Mackness B, Durrington PN, Mackness MI: Human serum paraoxonase. Gen Pharmacol 1998, 3 I:329-336.

16. Durrington PN, Mackness B, Mackness MI: Paraoxonase and atherosclerosis. Arterioscler Thromb Vasc Biol 200I, 2 I:473-480.
17. Mackness MI, Mackness B, Durrington PN: Paraoxonase and coronary heart disease. Atheroscler Suppl 2002, 3:49-55.

18. Ayub A, Mackness MI, Arrol S, Mackness B, Patel J, Durrington PN: Serum paraoxonase after myocardial infarction. Arterioscler Thromb Vasc Biol 1999, 19:330-335.

19. Mackness MI, Harty D, Bhatnagar D, Winocour PH, Arrol S, Ishola M, Durrington PN: Serum paraoxonase activity in familial hypercholesterolaemia and insulin-dependent diabetes mellitus. Atherosclerosis 1991, 86:193-199.

20. Akcay MN, Yilmaz I, Polat MF, Akcay G: Serum paraoxonase levels in gastric cancer. Hepatogastroenterology 2003, 50(Suppl 2):cclxxiii-cclxxv.

21. Akcay MN, Polat MF, Yilmaz I, Akcay G: Serum paraoxonase levels in pancreatic cancer. Hepatogastroenterology 2003, 50(Suppl 2):ccxxv-ccxxvii.

22. Weber WW: Influence of heredity on human sensitivity to environmental chemicals. Environ Mol Mutagen I995, 25(Suppl 26): $102-114$

23. Juretic D, Tadijanovic M, Rekic B, Simeon-Rudolf V, Reiner E, Baricic $M$ : Serum paraoxonase activities in hemodialyzed uremic patients: cohort study. Croat MedJ 200I, 42:I46-I50.

24. Haagen L, Brock A: A new automated method for phenotyping arylesterase (EC 3.I.I.2) based upon inhibition of enzymatic hydrolysis of 4-nitrophenyl acetate by phenyl acetate. Eur J Clin Chem Clin Biochem 1992, 30:391-395.

25. Eckerson HW, Wyte CM, La Du BN: The human serum paraoxonase/arylesterase polymorphism. Am J Hum Genet 1983, 35: II26- II38.

26. Valko M, Rhodes CJ, Moncol J, Izakovic M, Mazur M: Free radicals, metals and antioxidants in oxidative stress-induced cancer. Chem Biol Interact 2006, 160: I-40.

27. Valko M, Izakovic M, Mazur M, Rhodes CJ, Telser J: Role of oxygen radicals in DNA damage and cancer incidence. Mol Cell Biochem 2004, 266:37-56.

28. Dreher $D$, Junod AF: Role of oxygen free radicals in cancer development. Eur J Cancer 1996, 32A:30-38.

29. Kaynar H, Meral M, Turhan H, Keles M, Celik G, Akcay F: Glutathione peroxidase, glutathione-S-transferase, catalase, xanthine oxidase, $\mathrm{Cu}-\mathrm{Zn}$ superoxide dismutase activities, total glutathione, nitric oxide, and malondialdehyde levels in erythrocytes of patients with small cell and non-small cell lung cancer. Cancer Lett 2005, 227:133-139.

30. Gonenc A, Ozkan Y, Torun M, Simsek B: Plasma malondialdehyde (MDA) levels in breast and lung cancer patients. I Clin Pharm Ther 200I, 26: |4|-|44.

31. Davies HG, Richter RJ, Keifer M, Broomfield CA, Sowalla J, Furlong $C E$ : The effect of the human serum paraoxonase polymorphism is reversed with diazoxon, soman and sarin. Nat Genet 1996, I 4:334-336.

32. Rozenberg O, Rosenblat M, Coleman R, Shih DM, Aviram M: Paraoxonase (PONI) deficiency is associated with increased macrophage oxidative stress: studies in PONI-knockout mice. Free Radic Biol Med 2003, 34:774-784.

33. Lee $\mathrm{CH}$, Lee KY, Choe KH, Hong YC, Kim YD, Kang JW, Kim H: [Effects of oxidative DNA damage induced by polycyclic aromatic hydrocarbons and genetic polymorphism of the 
paraoxonase-I (PONI) gene on lung cancer]. J Prev Med Pub Health 2005, 38:345-350.

34. Kerridge I, Lincz L, Scorgie F, Hickey D, Granter N, Spencer A: Association between xenobiotic gene polymorphisms and nonHodgkin's lymphoma risk. Br J Haematol 2002, I I 8:477-48I.

35. Marchesani M, Hakkarainen A, Tuomainen TP, Kaikkonen J, Pukkala E, Uimari P, Seppala E, Matikainen M, Kallioniemi OP, Schleutker J, et al.: New paraoxonase I polymorphism II 02V and the risk of prostate cancer in Finnish men. J Natl Cancer Inst 2003, 95:8|2-8|8.

36. Antognelli C, Mearini L, Talesa VN, Giannantoni A, Mearini E: Association of CYPI7, GSTPI, and PONI polymorphisms with the risk of prostate cancer. Prostate 2005, 63:240-25I.

37. Stevens VL, Rodriguez C, Pavluck AL, Thun MJ, Calle EE: Association of polymorphisms in the paraoxonase I gene with breast cancer incidence in the CPS-II Nutrition Cohort. Cancer Epidemiol Biomarkers Prev 2006, 1 5:1226-1228.

38. Kafadar AM, Ergen A, Zeybek U, Agachan B, Kuday C, Isbir T: Paraoxonase 192 gene polymorphism and serum paraoxonase activity in high grade gliomas and meningiomas. Cell Biochem Funct 2006, 24:455-460.

39. Van Der Logt EM, Janssen CH, Van Hooijdonk Z, Roelofs HM, Wobbes $T$, Nagengast FM, Peters WH: No association between genetic polymorphisms in NAD(P)H oxidase p22phox and paraoxonase I and colorectal cancer risk. Anticancer Res 2005, 25: |465-| 470 .

40. Zieba M, Suwalski M, Kwiatkowska S, Piasecka G, Grzelewska-Rzymowska I, Stolarek R, Nowak D: Comparison of hydrogen peroxide generation and the content of lipid peroxidation products in lung cancer tissue and pulmonary parenchyma. Respir Med 2000, 94:800-805.

41. Zieba M, Nowak D, Suwalski M, Piasecka G, Grzelewska-Rzymowska I, Tyminska K, Kroczynska-Bednarek J, Kwiatkowska S: Enhanced lipid peroxidation in cancer tissue homogenates in non-smal cell lung cancer. Monaldi Arch Chest Dis 200 I, 56: I I0-I I4.

42. Aviram M, Rosenblat M, Billecke S, Erogul J, Sorenson R, Bisgaier CL, Newton RS, La Du B: Human serum paraoxonase (PON I) is inactivated by oxidized low density lipoprotein and preserved by antioxidants. Free Radic Biol Med 1999, 26:892-904.

43. Baskol G, Demir H, Baskol M, Kilic E, Ates F, Kocer D, Muhtaroglu S: Assessment of paraoxonase I activity and malondialdehyde levels in patients with rheumatoid arthritis. Clin Biochem 2005 38:95I-955

44. Baskol G, Baskol M, Yurci A, Ozbakir O, Yucesoy M: Serum paraoxonase I activity and malondialdehyde levels in patients with ulcerative colitis. Cell Biochem Funct 2006, 24:283-286.

45. James RW, Leviev I, Righetti A: Smoking is associated with reduced serum paraoxonase activity and concentration in patients with coronary artery disease. Circulation 2000, I0I:2252-2257.

\section{Pre-publication history}

The pre-publication history for this paper can be accessed here:

http://www.biomedcentral.com/1471-2407/7/48/prepub

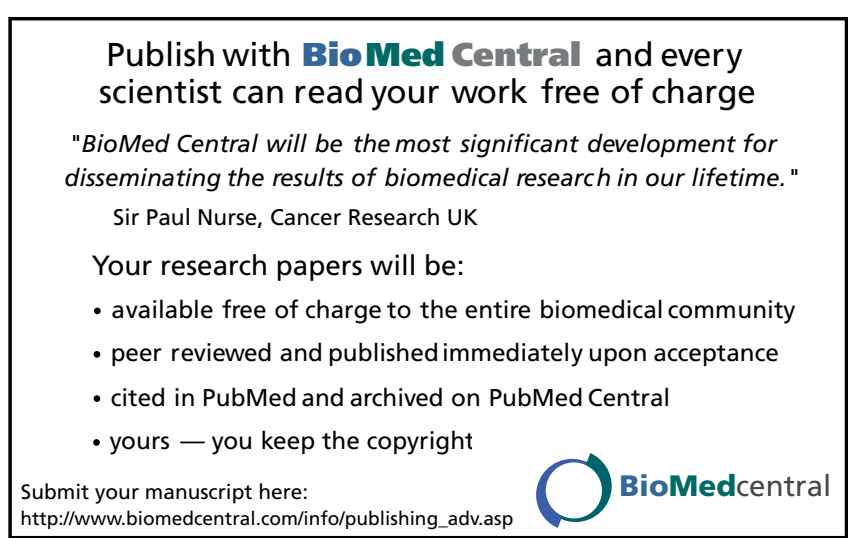

